\title{
The effect of transgenic cotton planting on soil microbial community
}

\section{structure based on PLFA analysis}

\author{
Ruihua Liu ${ }^{1 \mathrm{a}}$, Yan Wang ${ }^{1 \mathrm{~b}}$, Yingying Liu ${ }^{1 \mathrm{c}}$, Huifen Liu ${ }^{1 \mathrm{~d}}$, Jianning Zhao ${ }^{1 \mathrm{e}}$
}

1 College of Agronomy and Resources \& Environment, Tianjin Agricultural University, Tianjin

300384, P.R.China; 2 Agro-Environmental Protection Institute, Ministry of Agriculture, P.R.China

aemail 781648493@qq.com; bemail 1150741213@qq.com; 'email 1377088418@qq.com; demail paula913@126.com, corresponding author; eemail 372667613@qq.com

Key words: soil microorganism; transgenic cotton; phospholipid fatty acid

Abstract: To evaluate the effect of genetically modified cotton planting on soil microbial community structure, four cotton materials, genetically modified cotton 013011 (drought-resistance), SGK321 (insect-resistance) and non-transgenic cotton $\mathrm{TH} 2$ (drought-resistant receptor) and Shiyuan321 (insect-resistant receptors) were selected to analyze the microbial community structure in their planting soil at cotton flowering and boll opening by using PLFA technology. The results showed that only the percentage of the bacterial in the soil of non-transgenic cotton $\mathrm{TH} 2$ and Shiyuan321 were higher than that of the corresponding GM varieties, while, no regular change was found in the other microbes. No significant difference was observed in the microbial community structure of soil between planting transgenic cotton and non-GM cotton except that the gram-negative bacteria, fungi and actinobacteria showed temporary difference.

\section{Introduction}

The planting area of genetically modified (GM) crops increased from 1.7 million $\mathrm{hm}^{2}$ in 1996 to 185.1 million $\mathrm{hm}^{2}$ in $2016^{[1]}$. Currently, only GM cotton and papaya are approved for planting in China. As an important economic crop in China, the planting area of cotton is about more than 400 hectares per year, and more than $80 \%$ was GM cotton that is the largest GM crop currently. Mass commercialization of transgenic cotton planting brings great benefits, at the same time, its effects on soil microorganisms and soil ecosystem aroused people's concern increasingly ${ }^{[2]}$.

Microorganism is an important component of soil ecosystem, which participates in the material transformation and nutrient cycling, and has a direct impact on the structure and function of ecosystem. The change of microorganism activity and community structure well reflects the quality of soil ecosystem and soil health since its sensitivity to environmental changes ${ }^{[3-4]}$. In addition, the residual and root exudate of GM crops may have an effect on microbial community structure in soil. Whether and how GM crops planting affect soil microorganisms has become a research focus, but the results were not the same. The proportion of fungi in transgenic cotton soil gradually increased, indicating that continuous planting transgenic cotton could change the soil microbial community structure $^{[5]}$. However, no significant difference in microbial community species evenness (J), the dominance index (D) and Shannon Wiener index (H) was observed in rhizosphere soil between genetically modified soybean and their corresponding parents ${ }^{[6]}$. Planting transgenic maize had no significant effect on bacteria, nitrogen-fixing bacteria and actinomycetes ${ }^{[7]}$. The transgenic rice planting mainly affected the number of soil bacteria at rice tillering, booting and heading stages ${ }^{[8]}$. 
Phospholipid fatty acids (PLFA) is an important component of the cell membrane, and different microbes have different biochemical pathways to synthesize different PLFA. The microbial community composition and the change can be revealed by monitoring PLFA composition and quantity which has been widely used in analysis of soil microbial community structure ${ }^{[9]}$. This research used PLFA techniques to analyze the effects of genetically modified cotton 013011 (drought-resistance), SGK321 (insect-resistance) and non-transgenic cotton TH2 (drought-resistant receptor) and Shiyuan321 (insect-resistant receptors) planting on soil microbial community diversity, to provide theoretical basis for safety assessment of genetically modified cotton planting on soil environment.

\section{Materials and methods}

\section{Overview of the research area}

The experimental site was located in Wuqing District, Tianjin $\left(39^{\circ} 21^{\prime} \mathrm{N}, 117^{\circ} 12^{\prime} \mathrm{E}\right)$. The annual mean temperature was $11.6^{\circ} \mathrm{C}$, mean precipitation was $606 \mathrm{~mm}$, and the frost-free period was 212 days. The basic physic-chemical characters of experiment field soil were as follows: total $\mathrm{P}$ $0.79 \mathrm{~g} / \mathrm{kg}$, total $\mathrm{N} 0.63 \mathrm{~g} / \mathrm{kg}$, organic matter content of $18 \mathrm{~g} / \mathrm{kg}, \mathrm{pH} 8.24$.

\section{Materials}

Four cotton varieties (provided by the institute of cotton research, the Chinese academy of agricultural sciences) were divided into 2 groups, Group 1, TH2 (drought resistant receptor) and 013011 (drought resistance); Group 2, Shiyuan321 (insect-resistant receptor) and SGK321 (insect resistance).

\section{Experiment design}

The plot area was $300 \mathrm{~m}^{2}(20 \mathrm{~m} \times 15 \mathrm{~m})$, with $5 \mathrm{~m}$ wide protection line between two species. The application rates of $\mathrm{N}, \mathrm{P}$ and $\mathrm{K}$ were $200 \mathrm{~kg} / \mathrm{hm}^{2}, 100 \mathrm{~kg} / \mathrm{hm}^{2}$ and $60 \mathrm{~kg} / \mathrm{hm}^{2}$. No pesticide was applied during the whole cotton growth, and the other management measures followed as usual.

\section{Soil sample collection}

The soil samples were collected at two stages, blooming and boll opening period. $0-20 \mathrm{~cm}$ rhizosphere soil was taken from 5 cotton plants in each plot.

\section{Extraction of soil phospholipid fatty acids}

The phospholipid fatty acids were extracted from the soil samples according to the methods of Li and Xiao ${ }^{[10,11]}$.

\section{Naming of phospholipid fatty acid}

The phospholipid fatty acids were named referred to the method of Boss DA ${ }^{[12]}$ as shown in Table 1. 
Table 1 PLFA characterizing microbes

\begin{tabular}{|c|c|}
\hline Microbial group & Phosphoilpids fatty acid signatures \\
\hline Bacteria & 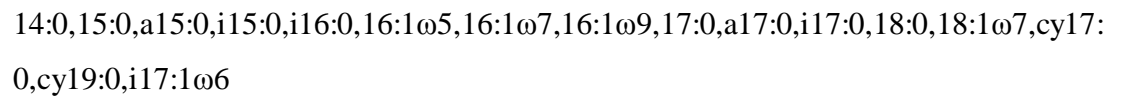 \\
\hline Fungi & $18: 2 \omega 6,9,18: 1 \omega 9,16: 1 \omega 5,18: 1 \omega 9 \mathrm{c}, 15: 1 \omega 6 \mathrm{c}, 16: 1 \omega 9 \mathrm{c}, 16: 1 \omega 7 \mathrm{c}, 17: 1 \omega 8 \mathrm{c}, 18: 1 \omega 9 \mathrm{c}, 18: 1 \omega 9 \mathrm{t}$ \\
\hline Actinobacte & 10Me16: 0, 10Me17:0, 10Me18:0 \\
\hline Antinomycetes & A17:0,I 17:0 \\
\hline Gram-positive bacteria & i14:0, I 15:0, a15:0, i16:0, i17:0, a17:0 \\
\hline Gram-negative bacteria & $16: 1 \omega 7 \mathrm{t}, 16: 1 \omega 9 \mathrm{c}, 16: 1 \omega 7 \mathrm{c}, 18: 1 \omega 7 \mathrm{c}, 18: 1 \omega 9 \mathrm{c}$, cy17:0, су19:0 \\
\hline
\end{tabular}

\section{Data analysis}

The PLFA content and percentage of biomarkers served as the control, marking the PLFA type of microbes, the differences in the components of microbial community composition were analyzed between GM and non-GM cotton planting soil by using t test through SPSS 17.0 software.

\section{Results and analysis}

The effect of transgenic cotton planting on the percentage composition of soil microorganisms

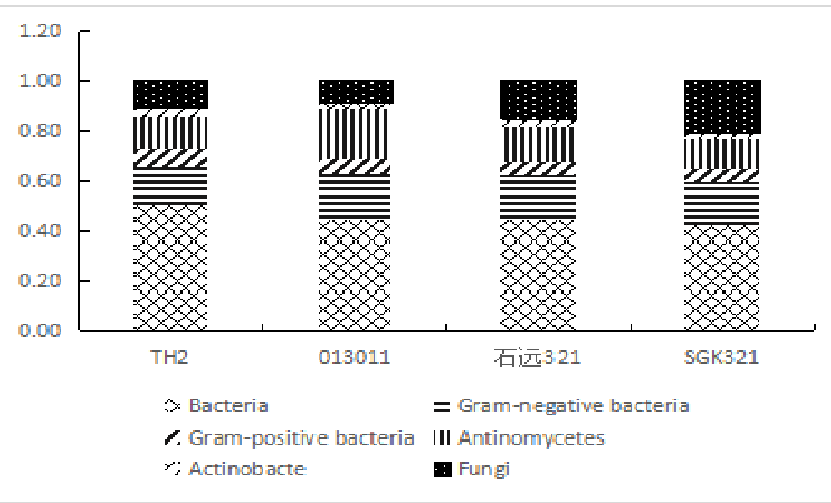

Fig.1 The proportion of different microbes in the soil of cotton at flowering stage

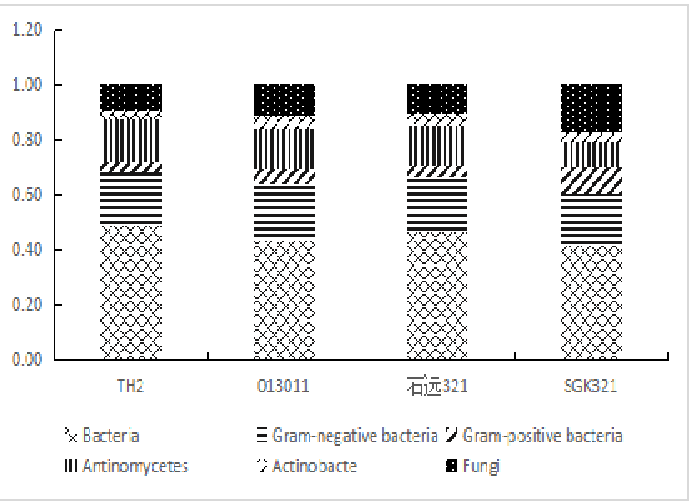

Fig.2 The proportion of different microbes in the soil of cotton at boll opening stage

The percentage of components of microbial community in different cotton planting soils was shown in Fig.1 and Fig.2. The percentage of bacteria in the soil planting non-GM cotton TH2 and Shiyuan321 were higher than that of planting GM varieties, but the percentage of gram-negative bacteria, gram-positive bacteria, anaerobic bacteria, fungi and actinomycete did not have a regular trend. During the blooming period, compared with 013011 (GM variety), the percentage of fungi in the soil planting TH2 (non-GM variety) was higher, while, the percentage of fungi in the soil planting Shiyuan321 (non-GM variety) was lower than SGK321 (GM variety). During the boll opening period, the percentage of fungi in the soil planting TH2(non-GM variety) and Shiyuan321 (non-GM variety) were lower than 013011 (GM variety) and SGK321 (GM variety).During the 
blooming period, compared with 013011 (GM variety), the percentage of anaerobic bacteria in the soil planting TH2 (non-GM variety) was lower, while, the percentage of anaerobic bacteria in the soil planting Shiyuan321 (non-GM variety) was lower than SGK321 (GM variety). During the boll opening period, compared with transgenic cotton, the percentage of anaerobic bacteria in the soil planting non-transgenic cotton was higher.

The effects of transgenic cotton planting on soil microbial community structure

Table 2 The structure of microbial communities in soils planting different cottons

\begin{tabular}{|c|c|c|c|c|c|c|c|}
\hline & Variety & $\begin{array}{l}\text { Bacteria } \\
\text { ( nmol/g ) }\end{array}$ & $\begin{array}{l}\mathrm{G}^{-} \text {bacteria } \\
(\mathrm{nmol} / \mathrm{g})\end{array}$ & $\begin{array}{l}\mathrm{G}^{+} \text {bacteria } \\
(\mathrm{nmol} / \mathrm{g})\end{array}$ & $\begin{array}{l}\text { Antinomycetes } \\
\text { ( nmol/g ) }\end{array}$ & $\begin{array}{l}\text { Actinobacte } \\
\text { ( nmol/g ) }\end{array}$ & $\begin{array}{c}\text { Fungi } \\
\text { ( nmol/g ) }\end{array}$ \\
\hline \multirow[t]{4}{*}{ Flowering } & TH2 & $18.73 \pm 1.32 \mathrm{a}$ & $5.76 \pm 0.69 b$ & $2.7 \pm 0.52 \mathrm{a}$ & $4.72 \pm 0.74 \mathrm{a}$ & $1.46 \pm 0.19 a$ & $3.91 \pm 0.13 \mathrm{a}$ \\
\hline & 013011 & $27.435 \pm 4.99 \mathrm{a}$ & $11.84 \pm 2.72 \mathrm{a}$ & $3.62 \pm 1.82 \mathrm{a}$ & $12.67 \pm 6.72 \mathrm{a}$ & $1.56 \pm 0.56 \mathrm{a}$ & $5.16 \pm 0.62 \mathrm{a}$ \\
\hline & Shiyuan321 & $21.54 \pm 4.26 \mathrm{a}$ & $8.65 \pm 1.42 \mathrm{a}$ & $2.46 \pm 0.14 \mathrm{a}$ & $6.72 \pm 1.23 \mathrm{a}$ & $1.87 \pm 0.92 \mathrm{a}$ & $7.18 \pm 1.62 b$ \\
\hline & SGK321 & $30.29 \pm 5.1 \mathrm{a}$ & $12.18 \pm 2.00 \mathrm{a}$ & $3.93 \pm 0.71 \mathrm{a}$ & $8.51 \pm 1.66 \mathrm{a}$ & $2.08 \pm 0.09 \mathrm{a}$ & $14.65 \pm 2.83 \mathrm{a}$ \\
\hline \multirow[t]{4}{*}{ Boll opening } & TH2 & $22.05 \pm 5.05 \mathrm{a}$ & $8.75 \pm 1.62 \mathrm{a}$ & $1.66 \pm 0.69 \mathrm{a}$ & $6.84 \pm 1.05 \mathrm{a}$ & $1.40 \pm 0.20 \mathrm{~b}$ & $4.23 \pm 1.48 \mathrm{a}$ \\
\hline & 013011 & $19.54 \pm 2.10 \mathrm{a}$ & $9.07 \pm 0.92$ & $2.71 \pm 0.66 \mathrm{a}$ & $6.33 \pm 0.64 \mathrm{a}$ & $2.21 \pm 0.19 \mathrm{a}$ & $5.09 \pm 0.59 \mathrm{a}$ \\
\hline & Shiyuan321 & $36.23 \pm 3.15 \mathrm{a}$ & $12.98 \pm 1.66 \mathrm{a}$ & $3.18 \pm 0.70 \mathrm{a}$ & $9.90 \pm 0.91 \mathrm{a}$ & $2.84 \pm 0.72 \mathrm{a}$ & $5.77 \pm 2.05 \mathrm{a}$ \\
\hline & SGK321 & $18.68 \pm 0.70 b$ & $8.45 \pm 1.12 \mathrm{a}$ & $4.45 \pm 1.49 \mathrm{a}$ & $4.04 \pm 2.67 \mathrm{a}$ & $1.59 \pm 0.27 \mathrm{a}$ & $7.82 \pm 1.27 \mathrm{a}$ \\
\hline
\end{tabular}

Note: Different letters within a column showed significant difference between different treatments $(\mathrm{P}<0.05)$.

The effect of transgenic cotton planting on soil microbial community structure was shown as Table 2. The results showed that at flowering stage, the content of gram-negative bacteria in the non-transgenic cotton $\mathrm{TH} 2$ soil was significantly lower than that in the soil planting transgenic cotton 013011 and the fungi content in the non-transgenic cotton Shiyuan321 was significantly lower in the soil of GM cotton SGK321. The actinobacteria in the soil planting non-transgenic cotton TH2 was significantly lower than that planting the transgenic cotton 013011, but the bacteria in the soil planting non-transgenic cotton Shiyuan321 was significantly higher than that in the soil planting SGK321 at boll opening stage. Such temporary differences in the soil microbial community structure between non-transgenic cotton and transgenic cotton planting were probably attributed to different growth stages and planting sites, but not to the cultivation of GM varieties. These results were consistent with other results ${ }^{[13,14]}$.

\section{Acknowledgements}

This work was financially supported by the genetically modified organisms breeding major proj -ect--effect of genetically modified maize and cotton on large soil animal community and AM fungi (2016ZX08012005-005).

\section{References :}

[1] Information on http://www.isaaa.org.

[2] J.A. Liang, Z.G. Zhang: Crops Vol. 4(2017), p.1.

[3] Z.W. Xu , G.R.Yu , X.Y. Zhang: Applied Soil Ecology Vol. 86(2015), p.19 . 
[4] L. Zelles: Biology and Fertility of Soils, 1999, 29 : 111-129.

[5] Y.S. LI, Q.L. Fan, K. Liu: Journal of China Agricultural University Vol. 23(2015), p.30 .

[6] L.J. Wang, G. LI, J.N.Zhao: Journal of Agro-Environment Science Vol. 32(2013), p.290.

[7] K.Liu , Y.S. Li , Q.L Fan: Journal of Shanxi Agricultural Sciences Vol. 43(2015), p.1138.

[8] X.W. Xiao , L. Sheng , M.S. You: Journal of Biosafety Vol. 20(2011), p.151.

[9] M.E Schutter, R.P. Dick: Soil SciSoc Am J. Vol. 64(2000), p.1659.

[10] Y.B. Li, B. Deng, Y.M. Liu: China Brewing Vol. 36(2017), p.74.

[11] R.F. Xiao, B.Liu, Y.J. Zhu: Journal of Plant Protection Vol. 44(2017), p.763.

[12] D.A. Boos, J.A. Fleck, K.M. Scow: Soil Biology and Biocheemistry Vol. 38(2006), p.1223.

[13] X.N. Gu, H.S. He, Y. Tao: Acta Ecologica Sinica Vol. 38(2017), p.4828.

[14] Y.J. Zhang, M. Xie, D,L. Peng: Chinese Journal of Applied Ecology Vol. 24(2013), p.2685. 